\section{Intersections}

Canadian Journal of Music

Revue canadienne de musique
Intersections CANADIAN JOURAL OF MUSIC

\title{
Novák's Lucerna and the Historiographical Problem of "Czech Modernism"
}

\section{Brian Locke}

Volume 26, numéro 1, 2005

URI : https://id.erudit.org/iderudit/1013244ar

DOI : https://doi.org/10.7202/1013244ar

Aller au sommaire du numéro

\section{Éditeur(s)}

Canadian University Music Society / Société de musique des universités canadiennes

ISSN

1911-0146 (imprimé)

1918-512X (numérique)

Découvrir la revue

Citer cet article

Locke, B. (2005). Novák's Lucerna and the Historiographical Problem of "Czech Modernism". Intersections, 26(1), 86-112. https://doi.org/10.7202/1013244ar
Résumé de l'article

L’opéra Lucerna (première en 1923) du compositeur tchèque Vìtězslav Novák est un exemple représentatif de la position difficile de la musique tchèque dans le cadre de l'historiographie du début du XX ${ }^{\mathrm{e}}$ siècle. En effet, les étiquettes " avant-garde » et " antimoderniste " ne conviennent pas pour décrire ses caractéristiques stylistiques. Un chef de file du modernisme tchèque pendant la fin de siècle, Novák a su transcrire musicalement la crise esthétique vécu par sa génération après 1918. La partition de Lucerna révèle une négociation complexe d'influences stylistiques diverses, telles l'impressionisme, le folklore et Strauss, en parallèle avec le modernisme international hésitant de la communauté tchèque au début de l'entre-deux-guerres. La finale sans éclat de l'opéra se fait l'écho du retour aux valeurs traditionnelles tchèques, en utilisant Smetana comme modèle anachroniste de l'opéra moderne.
Copyright (c) Canadian University Music Society / Société de musique des universités canadiennes, 2006
Ce document est protégé par la loi sur le droit d'auteur. L'utilisation des services d’Érudit (y compris la reproduction) est assujettie à sa politique d'utilisation que vous pouvez consulter en ligne.

https://apropos.erudit.org/fr/usagers/politique-dutilisation/ 


\title{
NOVÁK'S LUCERNA AND THE
}

\section{Historiographical Problem of "Czech Modernism"}

\author{
Brian Locke
}

The history of musical modernism - as told by postwar historians with a modernist agenda-notoriously avoided the obstacle of what to do with composers and communities that did not fit a teleological narrative supporting a "mainstream." Now that the heyday of the postwar avant-garde is long past and we have already conceded legitimacy to postmodernist alternatives in contemporary composition, scholars have begun to revisit composers of the early twentieth century-especially those who had supposedly deviated from a path later historians felt they ought to have taken. Often these composers, in the years since their deaths, suffered from the taint of conservatism, antimodernism, or some other label that may or may not reflect the significance of their œuvre in their day. Although the career of Strauss, post-Rosenkavalier, is the iconic example of such a deviation, he is joined by legions of others, including Zemlinsky in the absence of the Second Viennese School, Roussel in a predominantly neoclassicist France, and all but a few "representative" composers in East-Central Europe. Twenty-first-century scholars are faced with a quandary: whether to deal with these apparent anomalies in isolation (on their own terms, as it were, but potentially maintaining their perceived distance from the avant-garde), or to bring the marginalized back into serious historiographical discourse (regardless of the composers' impact in their time and place). The result is often a tension between understanding the composer's stylistic choices in an extremely localized context and assimilating them into the larger history of the early twentieth century at all costs.

The history of Czech musical modernism - as told by Czech historians with a nationalist agenda-illustrates this problem precisely, affording its representatives a status that, at first glance, seems disproportionate with the larger cultural history of the era. ${ }^{2}$ For most musicologists outside the Czech sphere, the very

1 Although not the first of their kind, Robert Morgan's Twentieth-Century Music and Paul Griffiths's Modern Music: the Avant-Garde since 1945 have often been criticized-by Richard Taruskin, Greg Sandow, and others-for organizing their histories around a narrowly defined membership of composers and excluding possibilities for alternative voices (Taruskin 1996; Sandow 2004). In this paper, I use the term "modernism" somewhat loosely, as it was used by critics and practitioners in the early twentieth century, to indicate a shifting scale of perceived stylistic adventurousness, cosmopolitan aesthetics, and/ or distance from nineteenth-century tradition.

2 The landmark work of modernist Czech historiography is the Dëjiny české hudebni kultury (History of Czech Musical Culture), the combined effort of the majority of twentieth-century Czech specialists during the late socialist period. In this work, apart from a detailed examination of musical life and the stylistic makeup of the prevailing compositional language (with a brief comparison to techniques 
existence of a "Czech modernism" is a hazy concept, tied perhaps to Janáček, Martinů, or some imagined middle-ground between their two divergent styles, both of which have only recently been dealt with as anything more than exceptions, let alone as members of a unified movement. To add to the confusion, the Czech modernist school (or "Česká moderna"), as preached and practiced in Czech historiography, refers also to a specific circle of Prague composers-including Josef Suk, Otakar Ostrčil, Ladislav Vycpálek-whose activities were dominated by the personality and compositional style of Vítězslav Novák (1870-1949). From this perspective, Czech modernism can be seen to contain stylistic components - a concatenation of belated impressionism, folklore, dense counterpoint, and, significantly, Straussian influences-that lie somewhat apart from the "modernist mainstream," by which I mean the Schoenberg-Stravinsky axis that led to (and validated) the postwar avant-garde. By comparison with this relatively narrow stylistic gamut, Czech modernism may indeed appear to deserve the labels of conservative or antimodernist (despite the best efforts of its composers who felt otherwise); as such, Novák and its other practitioners were written out of the history entirely.

Indeed, Novák's fate, both during his life and since, has been inextricably linked to that of Czech music in general, with its problematic blend of potentialities, revolutions, obstructions, and failings that prevented both his and his colleagues' work from reaching both a wider public and a stronger position in the discourse on modernism. Novák's opera Lucerna (The Lantern, 1919-22), composed at a crucial moment in his own career as well as the history of Czech music making, demonstrates the fine balance between acceptance and rejection, modernism and antimodernism, that every European artist faced in those times of cultural upheaval. Lucerna has the strange position of being both a pivotal work, central to the problem of modernist historiography, and a marginalized one, where perceived inadequacies relegated it to a position far from the avantgarde spotlight.

Much of the problem, of course, has to do with Novák himself, and therefore with Czech modernism itself. The Czechs in the early years of the century kept pace with the current of fin-de-siècle compositional practice, including timely forays into impressionist and Straussian palettes of harmony, orchestration, and melodic gesture-with Novák at the forefront of these explorations. During the years of the First World War, some artists (notably Suk, Ostrčil, and their younger contemporaries) delved into a quasi-tonal polyphonic realm reminiscent of Schoenberg's early expressionism, while Janáček finally burst into Czech consciousness with a new and highly idiosyncratic style, closest to Bartók in its distillation of East-European folklore. ${ }^{3}$ Nevertheless, despite the opening

elsewhere in Europe), there is little effort to come to terms with the status of Czech modernist composers beyond their own borders.

3 Suk's major wartime achievement was the single-movement tone poem Zráni (Ripening, 1918), preceded by the second string quartet Op. 15 (also one movement, 1911) in a similar vein. Ostrčil's opera Legenda $z$ Erinu (A Legend from Erin, 1913-19) best encapsulates the post-tonal implications of his highly expressionist polyphonic style (See further discussion of both composers in Locke 2006). Janáček, of course, had been active as a composer since the $1880 \mathrm{~s}$, but his breakthrough into wider acceptance is usually dated from the time of the belated May 1916 première of Jenufa in Prague. 
of so many promising avenues of modern expression in the last years of the Habsburg régime, the Prague compositional sphere soon hit an unforeseen obstacle-ironically, in the form of national and cultural independence in 1918.

The wave of international influences that spread across the Czech cultural sphere in the early interwar years did not create the atmosphere of limitless discovery that virtually all members of the artistic élite had eagerly anticipated. The direct contact with the music of composers such as Debussy, Stravinsky, Hindemith, and Milhaud, now available on a flurry of fad-driven concert programs, produced a corresponding wave of shock, discomfort, and fear among almost all composers whose careers had started prior to $1914 .{ }^{4}$ Their initial reaction instigated a large-scale retreat, by the mid-1920s, to relatively conservative aesthetic positions, in many cases behind those they had held in the fin de siècle; such a stance, for better or worse, would go on to characterize their generation until the rise of younger composers to prominence around 1930. This retreat away from "international modernism" (as they perceived it, excluding themselves) had a variety of causes that extended back well before independence. For one, in the midst of the war years, Czech society had experienced a pervasive trend of conservative nationalism in the face of their pending national selfdetermination. In music, this was manifested by a "Cult of Smetana" as the sole representative of Czech compositional practice, progressive in his own time and therefore eternally modern in the present: this ideology lasted through much of the interwar period, becoming increasingly anachronistic as the years progressed. Secondly, the Czechs' collective identity, already labouring under the complex of being a "small nation" within Europe, produced a sense of desperation that the little they had recently gained-i.e., through Czech modernism in its various budding forms - would be lost amid the onslaught of new influences from abroad. Lastly and most detrimentally, there circulated among critics and composers the idea that their somewhat conservative, hesitant modernism was morally higher than the international avant-garde, since Czechs had based their progressive aesthetic on the timeless model of Smetana. Emil Axman, sometime student of Novák and secretary of the Society for New Music, famously penned an article "Leave Aside Foreign Tongues, Speak Your Own!" that appeared in a respected music journal and seemed to encapsulate the isolationist spirit of the times (Axman 1924).

Certainly not every composer in interwar Czechoslovakia responded to Axman's reactionary call-to-arms. These years were among the most important for Janáček's career as an opera composer, and also witnessed Martinư's leap from the Czech sphere (via Novák's Conservatory class) to the world of Parisian neoclassicism. Alois Hába was beginning to lay the groundwork for a seminar in microtonal composition that would prove influential for the succeed-

4 In Prague the years 1919-20 witnessed a rise in the concert programming of modernist music from Western Europe; rhetoric in the contemporary criticism reflects a particular enthusiasm for all things French, often citing a "long-lost spiritual brotherhood" between the two cultures, unjustly separated by German hegemony. Although this openness abated sharply within a few months, its lasting effect was felt among individuals such as Martinů, who was inspired by the programming of Roussel at the Czech Philharmonic and subsequently travelled to France. Cf. Štěpán 1920. 
ing generation and form a vital connection to new music communities abroad. For a time, several other individuals carried on with prewar trends into a type of latter-day expressionism or constructivism, using dense orchestral textures, motivic webs, and rigorous contrapuntal techniques. ${ }^{5}$ Not insignificantly, the German-speaking community of Prague, long dormant in the compositional sphere, was beginning to show signs of life under Zemlinsky's leadership, with contributions made by Viktor Ullmann, Hans Krása, and Erwin Schulhoff. The Czech majority, however, including a significant number of younger composers, lapsed into a belated Smetanianism that cast out most modernist trends as ephemeral fashions and cloaked their own hesitant contributions in the rhetoric of culturo-political superiority, all the while employing a musical palette that, in the rest of Europe, had ceased to be fashionable at least fifteen years earlier. Often most vociferously, this group proclaimed their aesthetic standpoint to be the most representative of modern Czech ideals, based morally in tradition. By the première of Lucerna in 1923, Novák was among their number.

Things were not always so for the composer, long considered the leading light of a cosmopolitan élite in Prague, a city full of promise in the waning days of the Habsburg empire. ${ }^{6}$ Born in Southern Bohemia to a lower middle-class family, Novák was lucky to be part of a generation that was educated completely in Czech and supported by a battery of representative arts independent of the German hegemonic culture around them. By the late 1880 s, when the teenaged Novák made his way to Prague, the project of the so-called Czech Cultural Revival was virtually complete, with professional institutions for most aspects of musical education and performance-not to mention an intensely engaged publicfirmly in place. Novák enrolled at both Prague Conservatory and University, attending Tomáš Masaryk's lectures on philosophy, courses on musical aesthetics by Otakar Hostinský, and in the years 1891-92, the composition masterclass of Antonín Dvořák. Together with Josef Suk and a chosen handful of talented students, Novák blossomed under Dvořák's tutelage, which shaped his creative consciousness through a variety of instrumental genres; significantly, in these early stages Novák exhibited a headstrong tendency to provoke his mentor. Although in the first years of his professional career he remained under the watchful guidance of Dvořák, composing unassuming songs and chamber works for the bourgeois salons of Prague, it was not long before the young Novák exerted his artistic independence, as a "modernist," at the expense of his relationship with the older composer. ${ }^{7}$ By 1897 we can observe a substantial aesthetic shift in

5 The most successful representative of this style was Ladislav Vycpálek, whose Cantata of the Last Things of Man was acclaimed at the 1925 festival of the International Society for Contemporary Music.

6 The most valuable source for biographical data (and the sole monograph to date) on Novák is Lébl 1964.

7 Novák's rebellion from Dvořák can be dated most concretely from the time of his own Gypsy Songs op. 14 (1897), written as a response to Dvorák's better known collection; after this, Novák's second quartet op.22 was passed over in 1900 for first prize from the Czech Society for Chamber Music, on which Dvořák sat as a panelist, on account of its "decadence"; similarly, the daring Sonata eroica (at that time subtitled "Independence!") was refused anything more than an award of merit in 1901. Years later, 
Novák's creative energies, employing proto-impressionist harmonies, gleaned in part from scores by foreign composers circulating in Prague, but also a result of his new love, Moravian folksong. ${ }^{8}$ In this year he published the first of his many volumes of songs on folk texts, to be followed shortly by modern harmonizations of folk melodies and, most impressively, the use of intervallic, rhythmic, and harmonic motifs from Moravian and Slovak folk music as the basis for large-scale compositions around 1900. Indeed, Novák can be credited with the formation of a highly successful and personal style in the fin de siècle, similar to Bartók and Janáček in his assimilation of the parameters of folk music, but unique in applying them to an impressionist harmonic vocabulary and monothematic, freely contrapuntal forms. For the cosmopolitan musical sphere of Prague at the dawn of the twentieth century, it seemed the perfect blend.

For the first twelve years of the new century, Novák became the Czechs' leading composer, setting stylistic trends long before the acceptance of Janáček, and forging a ring of institutional and personal connections that would prove indispensable in the turbulent decades ahead. These years saw the creation of masterworks in most genres, including works for piano solo, orchestral tone poems, song-cycles, and chamber music. ${ }^{9}$ After encountering Salome in 1906, Novák also began to incorporate the urgency of Strauss's harmonic and gestural language with successful results. The crowning achievements of these years, and the two works on which most of Novák's reputation rests, are the "sea fantasy" Boure (The Tempest) for orchestra, soloists, and chorus, and the five-movement monothematic tone poem for piano solo, Pan (both 1910). This impressive start garnered him a following of critics from all sides of the political spectrum in Prague who proclaimed him the leader of the Czech modernist style. By the end of the decade, virtually every budding composer in the city was queuing up for private lessons with the young master, paving the way for his entrance into the faculty of Prague Conservatory in 1909. With a Czech modernist school of composition in place, Novák was poised to lead his contemporaries into the wide world of the European avant-garde.

The years 1912-1920 represent an important transition for both Novák and his community of composers in Prague, but not always for positive, or even musical, reasons. On the tail of his tremendous successes of the previous years, Novák embarked on the long-postponed project of creating an opera, progressing from the dramatic cantata The Wedding Shift and the one-act comedy Zvikovsky rarášek (The Zvíkov Imp, 1915) to the full-length nationalist opera Karlštejn (1916). In so doing, he made a significant contribution to the genre, since very

Novák wrote his cantata Svatebni košile (The Wedding Shift, 1913) as an open polemic against Dvořák's celebrated setting of the text.

8 Novák responded to claims that he had taken specific compositional devices from Debussy by stating that his music had been "impressionist" long before the latter had been known in Czech musical circles (Lébl 1964, 89).

9 The most prominent works are the Sonata Eroica for piano solo (1900); tone poems In the Tatras (1902), Slovácko Suite (1903), Of the Eternal Longing (1905), Toman and the Wood Nymph (1907), and Lady Godiva (1907); song-cycles Melancholie (1901), Valley of the New Kingdom (1903), and Melancholy Songs about Love (1906); the Piano Trio in d-minor, "Quasi una ballata" op.27 (1902) and the String Quartet in D-major op.35 (1905). 
few Czech composers had attempted operas since the death of Dvořák: Janáček's Jenuifa had not yet received its belated Prague première, leaving the field open to Ostrčil and a handful of dilettantes. All three of Novak's works employ his patented blend of influences from impressionism, folklore, and Strauss, now with the increasing admixture of polytonality in localized moments. Despite his anticipation of tremendous personal success as an opera composer, Novák's experience was not a happy one, owing largely to a series of ideological battles with contemporary critics, led by the antagonizing figure of Zdenèk Nejedlý (1878-1962). ${ }^{10}$ Although Nejedlý had personally backed Novák's achievements of the previous decade, the critic's crusade against the legacy of Dvořák in Czech music eventually placed Novák in the middle of the debate. Thus, when Novák co-signed a protest against Nejedly's tactics in late 1912, he unwittingly signed away the critical success of his future work. Nejedlý viciously attacked all three of Novák's theatrical efforts as undramatic, misrepresentative of Czech artistic values, and antimodern to the point of being downright reactionary (Nejedlý 1921). Comparing his compositional palette to the aesthetic paradigm of Strauss post-Rosenkavalier, Nejedlý claimed that Novák too had turned away from musical progress, ultimately showing the true shallowness of his "modernism." While none of these works, Karlštejn in particular, was deliberately composed to be reactionary-indeed, Novák in his own mind still followed a path to modernism - the effect of Nejedly's vituperative words was enough to instigate a personal and artistic crisis that became increasingly palpable across the remainder of the decade. Within a year of Karlštejn's première, Nejedlý himself orchestrated the Smetana Exhibition of 1917, ushering in the large-scale shift in Czech aesthetic values that I have described above as the "Cult of Smetana." By promulgating the belief that to be modern and Czech was to follow the model of the eternally progressive Smetana, Nejedlý and other critics effectively replaced their living modernist leader with one long dead.

Novák, despite his personal crisis, may not have realized at the time that his fate was sealed; nor, for that matter, did his younger contemporaries, thirsting for a new openness towards international cultural exchange upon independence in 1918. In the last months of the war, Novák and his students (notably Ladislav Vycpálek and Boleslav Vomáčka) produced a series of vocal pieces that reflected the turbulence of military conflict and national self-determination; Novák's Sila a vzdor (Strength and Defiance, 1917) uses the medium of unaccompanied men's choir to exhibit some of his most strident, quasi-expressionist harmonic language. Excited by the prospect of fulfilling his strong republican ideals, he quickly completed a series of celebratory choruses and marches, dedicated to his former professor (now "President-Liberator") Masaryk and the Czech legion-

10 Nejedlýs career as a critic and musicologist in Prague dominated the Czech musical sphere from the turn of the century to his death; his polemic attacks on composers, performers, and scholars who did not fit his conception of Czech music, past and present, prevented several careers (including, arguably, Novák's) from blossoming to their full capacity. After a turn towards left-wing politics in 1920, Nejedlý became a leading figure in the interwar communist movement, earning him high-ranking status after the socialist revolution in 1948. He is vilified for instigating a purge of university professors during the "show trials" of the early 1950s, as well as for implementing a state-wide curriculum that reflected his own ideology and remained the standard until the Velvet Revolution in 1989. 
naires, one of them a setting of "In Flanders Fields" by Canadian poet John McCrae. Novák also threw himself into the rebuilding of Czech cultural life in the new régime, personally taking charge of restructuring the Conservatory and sitting on advisory boards for most institutions, including a new federal ministry of culture. To complete his leadership of interwar music making in Prague, he set out in early 1919 to find a suitable theme for an opera that could stand opposite the timeless, nation-building works of Smetana, but that would also reflect current social issues. He turned to author Alois Jirásek (1851-1930), long beloved for his literary depiction of quasi-historical legends, with the idea of setting the stage play Lucerna, "a new, purely Czech theme, [in which] the motive of love for the homeland [is] linked with a social motive" (Novák 1970, 45). ${ }^{11}$ Much to his surprise, the tepid reception of the opera at its première in 1923 would finally demonstrate how removed his concept of modern opera was from the expectations of contemporary critics and audiences in Prague, signaling both a crisis of artistic direction for the city's musicians and ensuing obscurity for Novák.

Lucerna, as a representative of Czech modernist opera, embodies much of this crisis. Novák's assumption of Jirásek's appeal as the subject for a modern, "republican" opera was miscalculated, and his reliance on the "kaleidoscope of figures from the world of lords, peasants, and fairy tales" (Novák 1970, 45) proved out of step with the modern world and almost impossible to transfer to an operatic setting without crumbling into a series of loosely connected vignettes. Moreover, the opera suffers from an overly conservative, even smug, final scene, in which the good folk characters declare a victory for Czech traditional values amid a glorious wash of C-major. Lucerna's score has often been chastised as Novák's great turn away from the path of modernism, demonstrating a hesitancy to accept current trends from abroad and to lead Czech musical society through them. And yet, Lucerna is no Rosenkavalier, at least not in the iconic sense that Strauss's opera is often used to demonstrate a sense of aesthetic "betrayal" in the history of modernism. ${ }^{12}$ Rather, it reveals an intricate negotiation of most of the trends of European composition since the fin de siècle, of which Novák had been an acknowledged master just a few years before. As with many operas composed amid the breakdown of tonality, one can interpret the artist's aesthetic stance based on a close musico-dramatic reading of the work. As we shall see, Novák explores multiple stylistic paths for modernism in Lucerna, and

11 Jirásek's Lucerna had premièred at Prague's National Theatre in 1905 as a belated echo of the ideals of the Cultural Revival, and had received over a hundred performances by the time Novák's opera was completed. The play had already been set by the fifteen-year-old composer Emil Němeček in 1917, unbeknownst to the playwright, who initially refused his permission to Novák out of fear that the operatic Lucerna would outshine the spoken version. Eventually an agreement was reached, in which Jirásek's son-in-law, Hanuš Jelínek, would supply a versified libretto. Other operatic projects based on Jirásek's work include Kovařovic's 1897 opera Psohlavci and the "operatic scenes" Temno by the neoclassicist composer Iša Krejčí in 1944.

12 In this sense, Rosenkavalier is no Rosenkavalier either, since its score upholds Strauss's pathbreaking orchestral techniques that had already become a staple for the first modernist generation; for all its apparent distance from Salome and Elektra, Rosenkavalier can still be considered more "modernist" than Lucerna and many other Czech modernist operas. 
their apparent rejection in the final scene is anything but unequivocal. While such modernist moments are usually connected with the opera's negative, nonCzech characters, the sympathy the composer creates for these individuals casts doubt upon the implied negativity of their music. Thus, the opera as a whole reveals a lingering dissatisfaction with the all-too-convenient resolution provided in the finale; it enacts, in microcosmic form, the dilemma of the contemporary Czech artist in the modern European world.

The plot of Lucerna, as with much of Jirásek's œuvre, takes place in the late eighteenth century, during the so-called "dark ages" of Czech history when Austro-German aristocrats held the rural Czech population in a state of feudal quasi-serfdom. Jirásek's play, echoing trends from the late nineteenth-century Cultural Revival, deals in grand symbols representing nation, class, and gender, all glazed with the mysticism of a fairy tale. The sheer volume of characters in the work provided tremendous fodder for a composer such as Novák, gifted in the art of musical characterization. Nevertheless, as we shall see, the binary divisions between Czech/non-Czech and good/evil implied in Jirásek's text became easily confused when mapped onto a musical opposition of "traditional" versus "modernist" in the score-an inevitable fate, given the similar aesthetic conflict in Czech society at large. ${ }^{13}$

The action takes place in and around a village in Bohemia. The characters can be divided into three groups: foreigners and their agents, local Czechs, and supernatural figures.

\section{Foreigners and their agents:}

A young Princess (S), foreign landowner visiting the village for the first time, fair-minded

A Courtier (Bar), in the Princess's retinue, covetous of Hanička and the Miller's linden tree

A Bailiff (B), the Princess's representative, officious and cold-hearted

A Musketeer (B), assistant to the Bailiff, carries out his orders with threats

Mr. Franc (T), a bureaucrat

Žan (i.e., "Jean") and Terezka (spoken roles), the Princess's domestic servants

\section{Local Czechs:}

A Miller (Bar), headstrong and conscious of class differences, bonded to the Princess

His Grandmother (A), bearer of legends from the past and warnings for the future

13 It is worthwhile to mention that these binarisms are only implied (however strongly) by Jirásek's use of fairy-tale archetypes, and that a closer reading of the text reveals undercurrents similar to those prevalent in Novák's opera. 
Hanička (S), the Miller's ward, desired by the Courtier, the Miller, and Míchal

Zajíček (T), a young teacher's assistant, obsequious, desperate to please the Princess

Klásek, Zima, Sejtko (spoken roles), village musicians, coarse and superstitious

Mrs. Klásková (A), Klásek’s wife, jealous, suspicious, and self-righteous

\section{Supernatural figures:}

Míchal (falsetto tenor), melancholy water-sprite desperately in love with Hanička

Ivan (basso profundo), grumpy water-sprite searching for peace and quiet

The plot hinges on the Princess's first visit to the village, an event that provokes the Miller's resistance to servitude: at stake are his national pride, his linden tree (or lípa, the Czech patriotic symbol par excellence), and the freedom of Hanicka (who becomes a symbol of Czech innocence and youth). Central to the controversy is the lantern of the opera's title, which, as the Grandmother informs us, is a symbol of the family's subjection to the aristocratic landowners, who traditionally have used generations of the Miller's forebears to guide their steps by lamplight. ${ }^{14}$ As the opera progresses, we learn that members of the Princess's entourage seek to cut down the linden tree and abduct Hanička, although the reasons for these deeds are never clearly stated; furthermore, the Princess becomes increasingly attracted to the Miller and attempts to lure him away from his home environment. In the end, all three dangers are averted, and the Miller and Hanička preserve the tree and the sanctity of Czech tradition. To this skeletal dramatic structure, Novák added a score that, on many occasions, demonstrates a remarkable gift for innovative orchestration and overall symphonic conception, but whose vocal writing relies heavily on the operatic models of Smetana and Dvořák. While the result is certainly more "singable" than the composer's earlier efforts (and, indeed, most of the early modernist repertoire), certain of the characters often directly mimic their more famous prototypes: the Grandmother echoes Ježibaba, and the Princess her counterpart, in Dvořák's Rusalka; the Miller's lofty, moral tone resonates with Smetana's heroes, but also with Jan Kozina Sladký from Kovařovic's Psohlavci, one of the most popular operas of the Czech fin de siècle. With all these illustrious forebears and the pressures of the modern era, it would be a challenging task for Novák to find an individual expressive voice and still do justice to a plot full of complex dramatic interrelationships and culturo-political allusions.

The opera opens in the mill with the Grandmother's prophecy, predicting that the days of Czech subjection to foreign rule will end in the glorious re-

14 The Miller's family's subjection is, in fact, only symbolic, since their lantern-duty is considerably less onerous than the hard physical labour demanded by aristocrats in the robota system of indentured manual servitude. The lantern's ambivalence is reflected in Hanicka's "mistaken" appreciation for its beauty, as well as in the luminous musical symbol for it in Novák's score. 
turn of Saint Wenceslas. Her tale, accompanied by some of the most discordant music in the score (and a mill-wheel motive reminiscent of Janáček's Jenüfa), serves as a link to a more famous prophecy in the Czech operatic repertoirethat of Libuše, Smetana's great heroine. In many ways, this scene encapsulates the problem of Novák's Lucerna in its day, written after the day of liberation had already passed; caught between two régimes aesthetically worlds apart, it was apropos of neither. ${ }^{15}$ Significantly, Novák wrote this scene (totaling seventyseven measures, $1-7)^{16}$ in one breath at the start of his task in early 1920, but, suddenly facing a severe stylistic crisis, broke off composition for some eighteen months, the longest and most doubt-filled hiatus of his career.

When he continued work on the opera in mid-1921, his aesthetic direction had palpably changed: what had begun with the epic scope of post-Wagnerian music drama now fractured into a variety of approaches, embracing a fair degree of stylistic contradiction. As critics remarked after the première, the flow of Novák's overall musico-dramatic narrative was compromised by his subdivision of the score into discrete characteristic scenes, with conservative music predominating for Hanička, Zajíček, and many of other characters in aria-like passages. ${ }^{17}$ Indeed, with the exception of the altercation between the Musketeer and the Miller over the latter's refusal to light the lantern (9-10), much of Act One dwells in a comfortably tonal realm, albeit coloured by varying degrees of folklore- or impressionist-inspired modal mixture. In isolated moments this crystallizes into a blended style of bitonality, as with the Miller's theme of rebellious defiance, where the bass line presents a solid tonic-dominant motion in Fmajor under a melody that suggests a-minor/lydian (example 1,11). Hanička's subsequent folk-like strophic song (example 2, 17-18), its text presaging the threat to the linden tree, underscores the purity associated with Czech tradition: it reveals a diatonic melody with irregular internal repetitions over a reduced accompaniment. Novák follows this idyllic moment with two comic scenes,

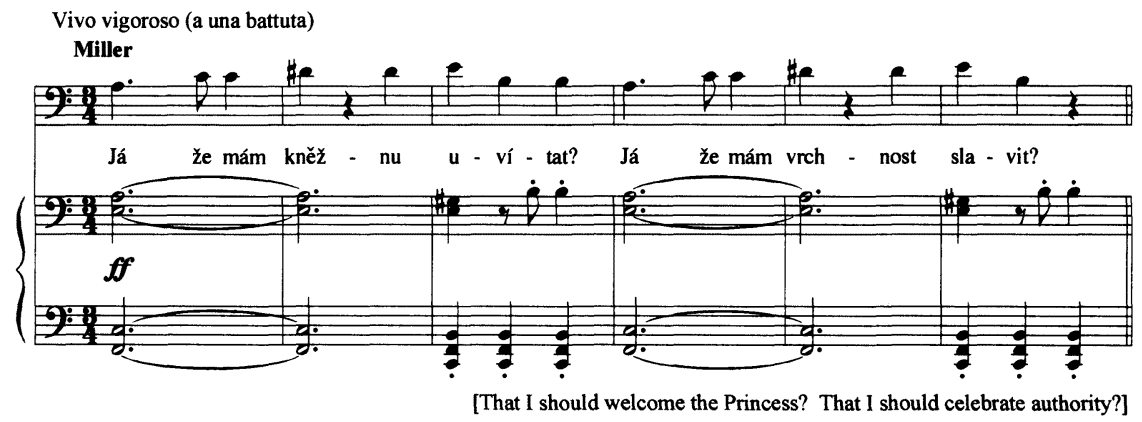

Example 1. The Miller's "rebellious" motive (Novák 1923, 11, bars 10-15)

15 This difficulty is, of course, absent from Jirásek's 1905 play, written thirteen years before independence.

16 The numbers in parentheses throughout this analysis refer to pages in the piano-vocal score, Novák 1923. The Supraphon CD recording, released in 2002, provides an excellent and faithful rendition of Novák's original version, with only one minor cut to separate the two scenes of Act Three.

17 Doležil 1923, Nejedlý 1923; see discussion below. 
one in which Zajíček relates his plans for a musical "cassation" performed by the townsfolk in honour of the Princess (19-30), the second describing the precipitous arrival of Mrs. Klásková in search of her drunken husband. Her aria (37-41), whose rhythmic idiosyncrasies are reminiscent of contemporary Janáček without the harmonic experimentation, contrasts in character with the succeeding, gentler scene between Hanička and the Grandmother, who discuss the lantern in unequivocally tonal terms (48-59). Klásek's entrance introduces yet another eclectic element into the mix: Novák characterizes him and the other lower-class individuals using the latterly re-popularized technique of spoken melodrama, first explored by Czechs in the late eighteenth century and rediscovered by Fibich, Foerster, and others just before 1900. Klásek's orchestral accompaniment, somewhat unpredictable in its variety of gestures, includes reference to the cassation, to be performed by him and others on wind instruments; accordingly, a quartet of E-flat clarinets and horns plays a jovial march melody, whose semitonal (i.e., "out of tune") clusters provide some of the more progressive harmonies in the act, albeit in the guise of ridicule (ironically, of local Czech music making, example 3,62). The final cameo appearance of Act One is reserved for the water-sprite Míchal, who sadly sings of his longing for Hanička in a stuttering falsetto, alongside characteristically "grotesque" minorseconds in the bassoon and harp (example 4, 73-74).

The second act, taking place outside the mill, does little to dispel the piecemeal quality of Novák's score, in that several more occasions of "characteristic music" are necessary to define the new personalities appearing for the first time. First among these is the lugubrious Ivan, whose two ariettas, solidly in c-minor and D-flat-major, respectively, are interrupted only by Míchal's teasing (81-87). The arrival of the Courtier and, subsequently, the Princess, introduces a genteel minuet of the type found in Puccini's Manon Lescaut and Strauss's Rosenkavalier, ${ }^{18}$ and the following aria for the Princess continues in a similarly elevated, if pretentious, tone; her sentiments, expressing a longing to be transformed by new experiences, are echoed in her motive, which displays a clear tonal focus but allows for developmental flexibility (example 5, 100-06). An encounter between the Miller and the Bailiff reinforces the three central points of conflict that drive the plot: the Miller rebelliously refuses to carry the Princess's lantern, and rejects the Courtier's encroachment on either the linden tree or Hanička, in musical terms that bespeak a nobility higher than that of the aristocrats. The music used to describe the tree, recurring throughout the opera, employs rich orchestration in a wide range amid long, sweeping phrases, oscillating between A-major and e-minor chords (example 6,111-12). These moments of transcendence serve to pique the romantic interest of the Princess, who approaches the Miller and requests that he fulfill his obligation as lantern-bearer, if only for the chance to be alone with him at a hunting-lodge in the forest. Unwillingly-if somewhat inexplicably-he obeys, and their departure precipitates a series of

18 I am indebted to Derek Katz for pointing out the Harmonie-style wind band, common to both Rosenkavalier and Lucerna, which suggests both the time period and the social class in question. 



[When they cut (the tree) for the first time, the wood sighed]

Example 2. Hanička’s folk-like song (Novák 1923, 17, bars 1-6)

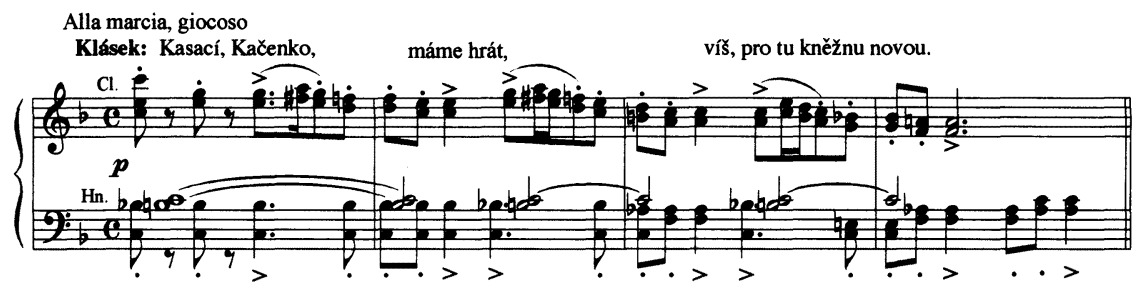

[Katya, we have to play a cassation for that new Princess.]

Example 3. The village musicians' "out-of-tune" cassation (Novák 1923, 62, bars 12-15)



[Hanička, Hanicka, my sunshine!]

Example 4. Míchal's characteristic music (Novák 1923, 73, bars 12-13; 74, bar 1) 


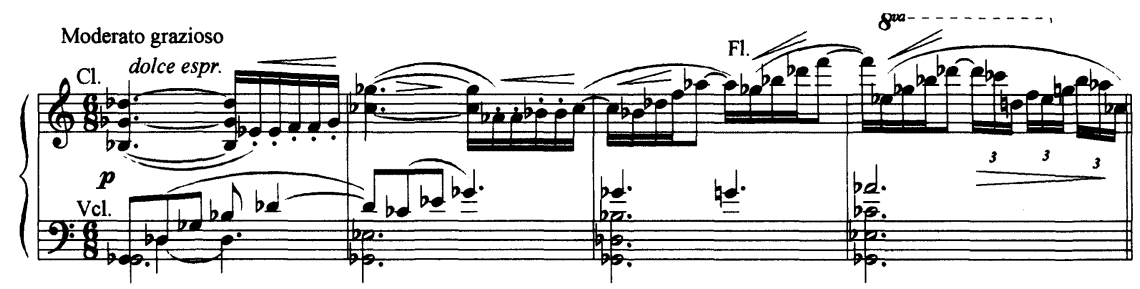

Example 5. The Princess's motive (Novák 1923, 100, bars 9-12)

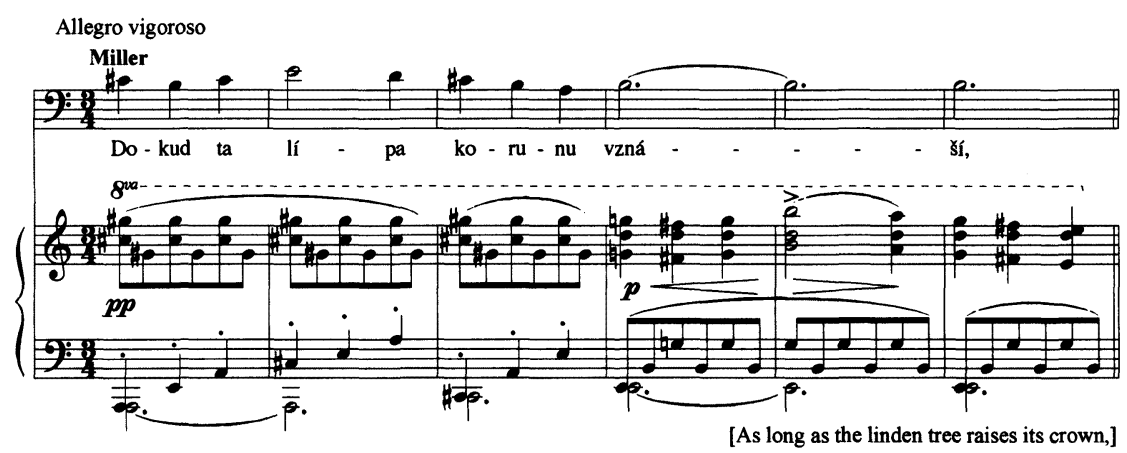

Example 6. The linden tree music (Novák 1923, 111, bars 16-17; 112, bars 1-4)

similar forays into the woods (pace, Sondheim!): Zajíček and the musicians to play their cassation for the Princess; Mrs. Klásková to find her husband; the Courtier and Bailiff to find the linden tree; Hanička to warn the Miller; and the ever-hopeful Míchal to be alone with Hanička. With half the opera and most of the dramatic activity complete, the stage is finally set for Novák's music to develop beyond the static vignettes that have hindered it since the very beginning.

In Act Three the highly referential quality of Novák's music also finally appears in its full flowering, demonstrating the composer's familiarity with the scores of his contemporaries throughout Europe. As Otakar Šourek noted (Šourek 1923, 3 ), the second half of Lucerna is carried by the orchestra, which develops all the previous characterizations in a much more meaningful way; Novák here establishes a palette of harmonic, gestural, and especially timbral devices that reveal a direct link to most of the contributions of his early-modernist generation. While the on-stage action is still divided into discrete scenes, the throughcomposed quality of the music serves to provide a much more unified sense of musico-dramatic narrative.

Much of this effect is a result of Novák's attention to capturing atmospheric detail, right from the beginning of Act Three. Situated in a moonlit forest, the music opens with a passage of non-functional chords centering around a lowerneighbour figure in the solo horn; Novák inserts a series of bitonal juxtapositions, including a-minor/D-major, e-minor/ $\mathrm{B}^{\mathrm{b}}$-major, and A-major/B-major (example 7,128 ). Both these and their orchestral treatment-divided string 



Example 7. Opening measures of Act 3 (Novák 1923, 128, bars 1-11)

voices with celesta in alternating registers-display an obvious debt to the opening of Debussy's Pelléas et Mélisande, which had its belated Prague première in November 1921, just as Novák was recommencing work on Lucerna. The first scene continues this mood through an equally polytonal reiteration of the musicians' cassation, now harmonized with chromatically ascending triads that no longer sound out-of-place (or even out of tune) in the new context. Curiously, the supernatural sounds of the forest, rendered as an orchestral tour de force and coupled with the use of melodrama, recall the Wolf's Glen Scene of Weber's Der Freischütz, particularly in the use of offstage ("uhui"-like) vocalizations. The blundering musicians having been scared off by the Samiel figure-here named Hejkal-in a frenzy of chromatic parallelisms, the Miller and Princess are free to enter the clearing and begin the psychological development of the opera.

Although Novák duly scales back his modernist orchestral explorations for these more refined characters, he replaces it with a harmonic subtlety that enhances our understanding of both the simple, diatonic minuet (which pervades the opening of the scene, 134-35) and the non-functional, impressionist passages at the beginning of the act. In this scene, the opera's two main characters, separated not only by class and culture, but also by motivation for being in each other's presence, enact a gradual rapprochement that is constantly, tantalizingly entertained until the final outcome of the plot. Novák accomplishes this delicate emotional drama by means of subtle gradations of timbral and harmonic colour, beginning with a section that recalls the "Liebe- und Lenzlied" from Die Walküre, representing the Miller's first moment of empathy with the Princess (example 8a-b, 137). She responds in kind, exulting in the discovery of the linden tree with a transcendent passage of extended tertial harmony: her melody suggests $\mathrm{F} \#$-major over a lush $\mathrm{d} \#$-minor accompaniment that riddles the score with cross-relations, effecting an impressionist weightlessness made active by a constant, post-Wagnerian cadential urgency (example 9,138 ). The Miller begins to describe to her the linden tree's symbolism, "of a sad kingdom, its crown lost, of injury, suffering, of age-old glory and decay, centuries of subjection," quickly winning her sympathies to the Czech cause with music that 


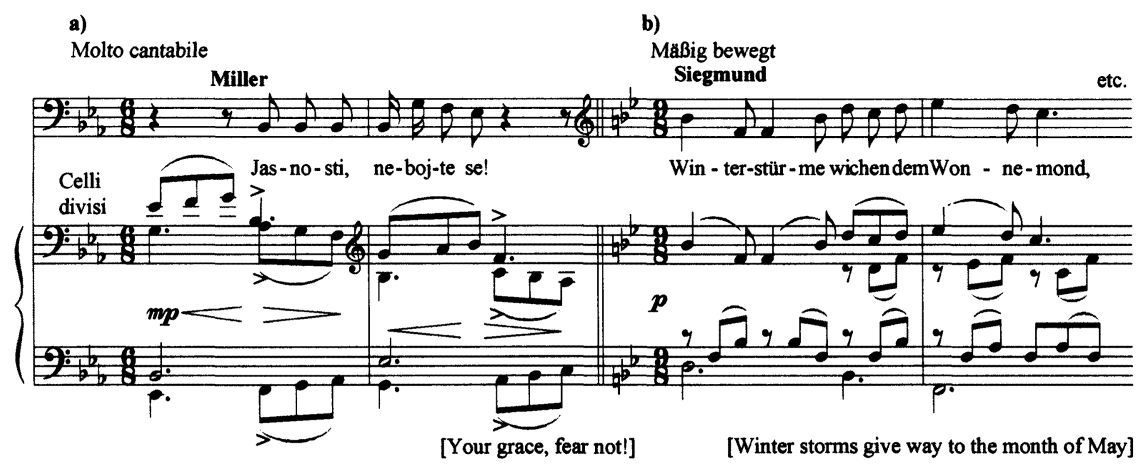

Example 8. 8a) The Miller's empathy towards the Princess (Novák 1923, 137, bars 1-2). $8 \mathrm{~b})$ The Liebe- und Lenzlied (Wagner, Die Walküre, Act 1 sc. 3)



Example 9. The Princess's "transcendent" extended tertial harmony (Novák 1923, 138, bars 10-13)

is anything but national. Interestingly, only the approach of the awkward (i.e., "local Czech") cassation music robs them of a deep moment of understanding, aglow with the music that opened the act; the Princess, now in love with the vital presence of the Miller, exclaims, "Unhappy cassation! Such a moment will never return," and they flee in the effort to postpone the disruption, leaving the lantern behind.

Novák's music, however, continues the dark, modernist world of the nighttime forest along multiple stylistic paths. The musicians' instrumental signals to find each other are again amusingly bitonal, now recreating the acoustic effect of distance (example 10,146-48). Much more impressive, however, is the rest of scene one, given over entirely to Míchal's interaction with the humans in the forest: it is here that we are fully brought to sympathize with the melancholy water-sprite and the out-of-place music that accompanies him. Eager to find Hanička, he sings a folk-like song in shifting meters, whose melody firmly outlines an optimistic F\#-major, but is harmonized in a lamenting $\mathrm{e}^{\mathrm{b}}$-minor, the enharmonic equivalent of its relative minor. The now-familiar tertial juxtaposition is made more acute by the timbral blend - the falsetto voice, English horn grace notes, and harp recalling the Falcon from Strauss's Die Frau ohne Schatten, the raspy trombone choir hearkening back to Don Quixote's sheep (example 11, 149-50). The overall effect pres- 




Example 10. The musicians' bitonal acoustic effects (Novák 1923, 147, bars 24-26; 148, bars 1-3)
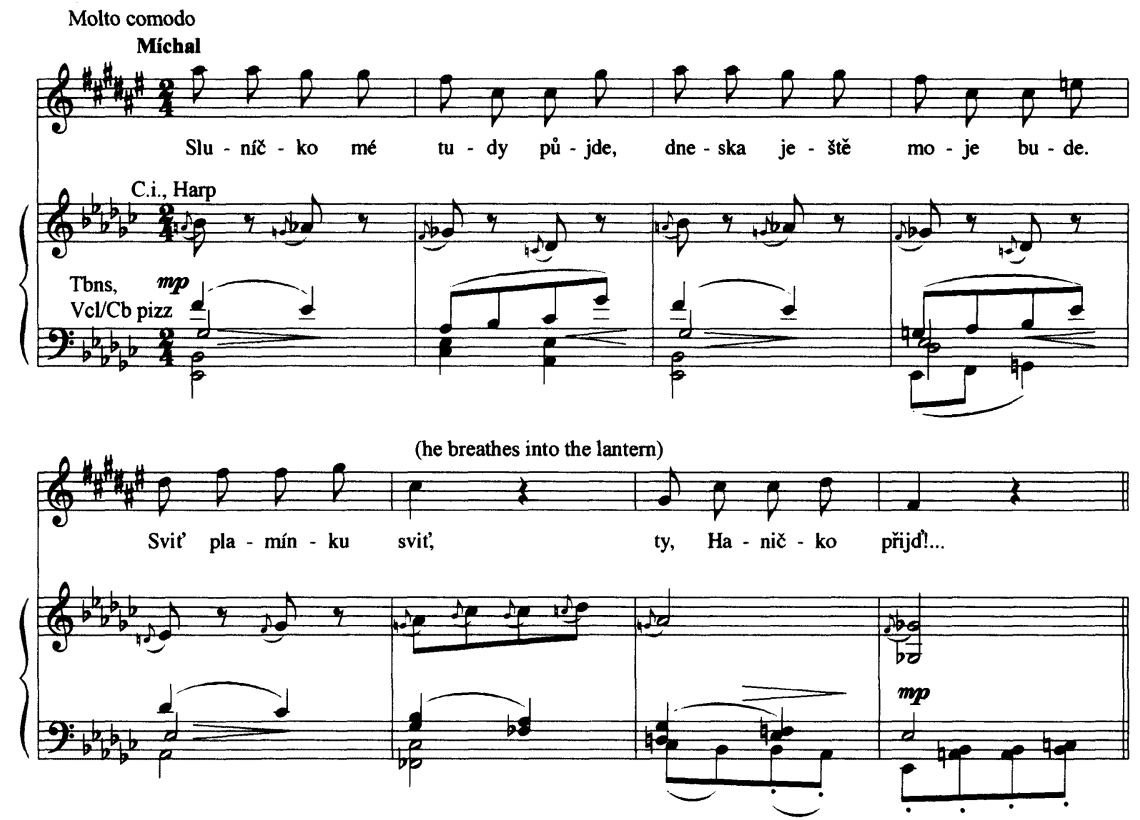

[My sunshine will come this way, today will still be mine. Shine, little flame, shine; you, Hanixka, come.]

Example 11. Míchal's folk-like song (Novák 1923, 150, bars 3-10)

ents a combination of the heartfelt and the insipid familiar from Prokofiev's brand of neoclassicism. Míchal's distinctive minor seconds persist through the following scene, in which he scares off the Musketeer and Franc, only to return with a triumphant iteration of his song. ${ }^{19}$ His fun is ruined, however, by an encounter with the shrewish Mrs. Klásková, who sees through his attempt to pass as a travelling ribbon salesman and sends him marching to the Miller with the forgotten lantern, diluting his modernist idiosyncrasies in the process.

The second half of Act Three, set in the hunting lodge, presents a brief respite from the musical momentum built up in the previous scene; from this point onwards, the consequences of the characters' interaction draw toward a resolution of the plot. To this idyllic spot the anti-social Ivan has come, ignorant of the approaching torrent of people; Novák depicts the static serenity of his natural

19 Novák must have thought this scene (the only one involving both Míchal and the lantern) sufficiently representative of the entire opera to select it as the basis for the cover art of the vocal score, Novák 1923. 
surroundings with a timely quote from his own piano tone-poem Pan, monumentally pentatonic in chords centering on $\mathrm{F}$ (example 12,166 ) ${ }^{20}$ Ivan's peace is disturbed by the somewhat irrelevant episode of the servants Žan and Terezka, newly arrived to prepare for the Princess's arrival; Žan tells Terezka a ghost story, but is interrupted in turn-amid full-orchestral parallel chords evocative of the contemporaneous Turandot-by the frightening appearance of Ivan, as if on cue (example 13, 174). ${ }^{21}$ The idyll returns with the entrance of the Miller and Princess, the latter so enraptured by the magical surroundings that she utterly transcends her previous coquetry and merges her music with the prevailing impressionist harmonic and gestural material. Not even the musicians' cassation, now seamlessly blended with the other orchestral melodies (which themselves have long since adopted the "out-of-place" bitonal inflections), can break the spell, and she turns to the Miller with an offer of equal status, riches, and the power to help his fellow Czechs, all through the desire to preserve this feeling-and him-in her heart. Her motive erupts into an inspired B-major climax before ebbing into a slower, chromatic version of itself (example 14, 184-85).



Example 12. Quotation from Pan for Ivan's entrance in Act 3, sc. 2 (Novák 1923, 166, bars 17-21)

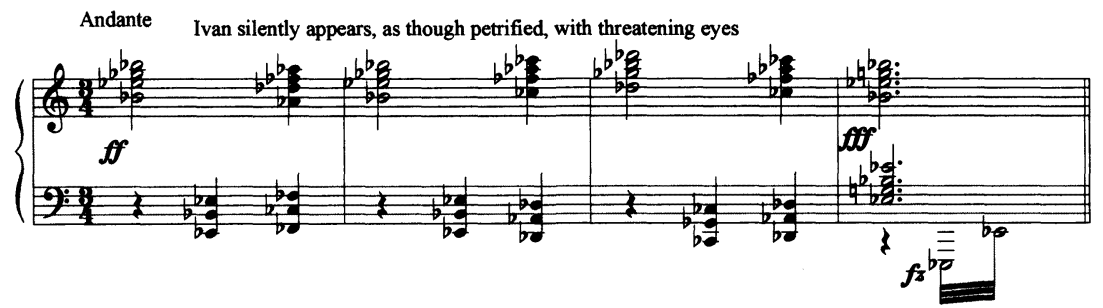

Example 13. Turandot-like parallel chords (Novák 1923, 174, bars 9-12)

20 There are three other musical quotations in Lucerna, beginning with an embedded excerpt of the Saint Wenceslas Chorale in the Grandmother's prophecy (6-7); the Musketeer boasts of his (false) bravery to the tune of the Prinz Eugen Lied (152-53); and Mendelssohn's wedding march appears skillfully intertwined with the cassation music at the mention of Zajiček's forthcoming nuptials (234). Novák was famed for musical jokes such as these. In addition, the text of Míchal's exhortation for the moon to shine ("Svit, měsičku, svit," 155) strongly recalls the refrain from Erben's famous ballad, Vodník (Erben 1982, 101).

21 The similarity to Turandot, although certainly coincidental, is reinforced by the heavy percussion (particularly tam-tam) shots in both cases. Cf. Puccini, Turandot, Act I sc.l. 


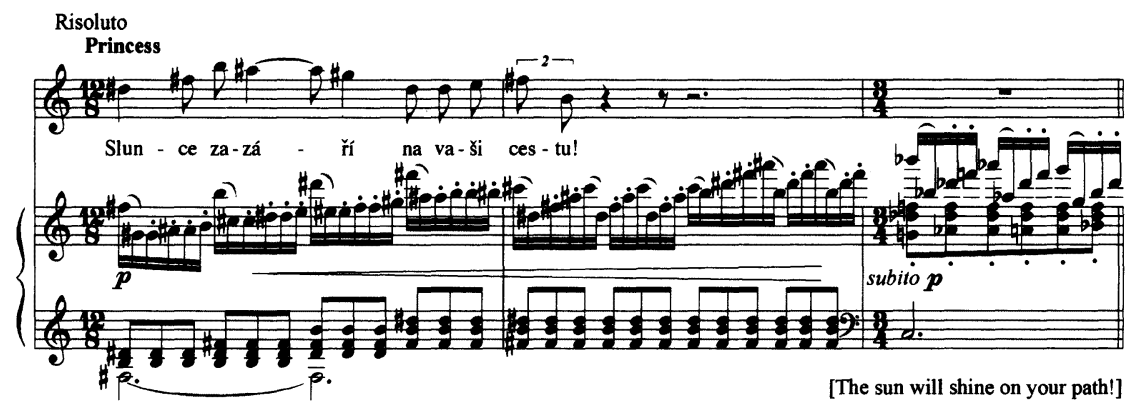

Example 14. Climax of the Princess's “seduction" (Novák 1923, 184, bars 3-5)

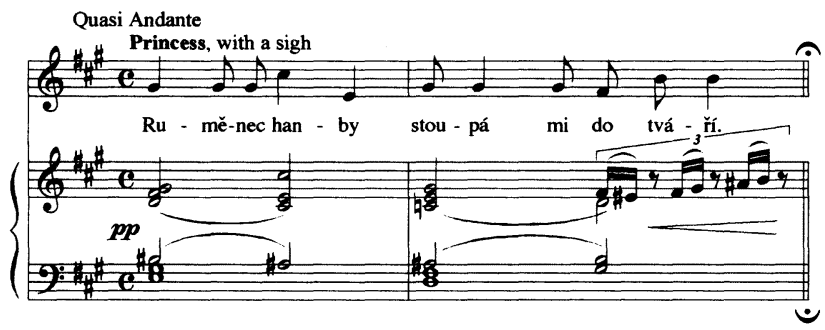

[The blush of shame rises to my cheeks.]

Example 15. Augmented chords revealing the Princess's grief (Novák 1923, 191, bars 13-14)

Both characters in this moment stand on the cusp of transfiguration into their social and musical opposites.

It is the mundane Mrs. Klásková who shatters the idyll, suddenly and irrevocably, as she enters in pursuit of the fleeing Míchal. When she relates to the Miller everything that has transpired regarding the linden tree and Hanička, he flies into a rage at the Princess, believing her promises to be part of the ploy to deprive him of his treasured possessions. He twists both her words and music into a distorted version of their earlier beauty, and she, unable to deny her guilt as he rushes away, can only express shame at her loss of dignity and love in the same moment: the directionless augmented chords that serve as her accompaniment encapsulate her tragedy (example 15, 191-92). The final moments of the act carry this poignancy forward in a different light, as Míchal seeks consolation in the begrudging Ivan, who advises him to give up the fickle world of human women. Míchal, tragicomically saddened by the realization of his fate, declares his resolution to go out into the world; in the final measures of the act, he bids his beloved Hanička farewell alongside a tortured, even shrill rendition of her motive in parallel ninths, possibly the most desolate music in the opera and the furthest away from musical or emotional resolution (example 16, 196).

The orchestral prelude to Act Four enacts a microcosm of its entire musical and dramatic trajectory: from fin-de-siècle modernist chaos to self-satisfied resolution, the moral high ground of tradition. Novák begins with a full orchestral, 


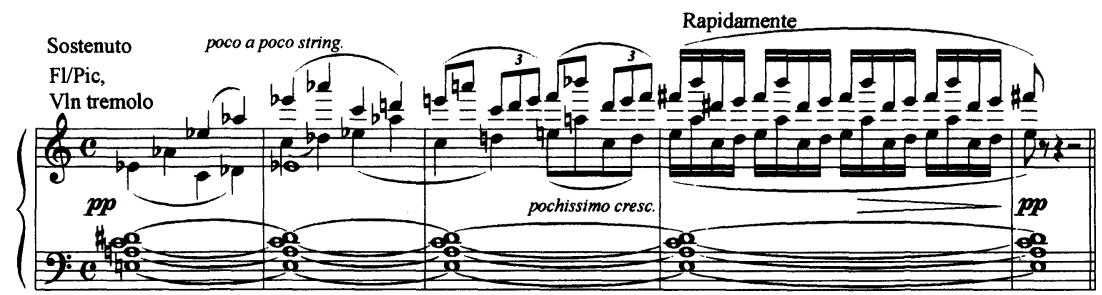

$\mathrm{Hns}, \mathrm{Vla} / \mathrm{Vc}$ tremolo col legno

Example 16. Hanička’s motive in parallel ninths (Novák 1923, 196, bars 8-12)

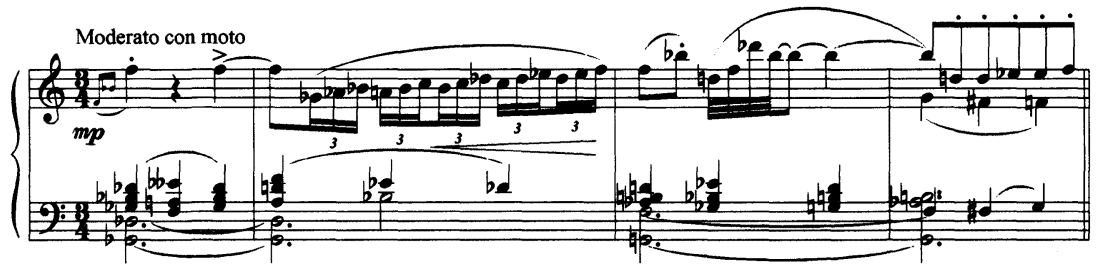

Example 17. Tonal disorientation during the nymphs' dance (Novák 1923, 211, bars 18-21)

heavily chromatic development of Hanička's motive, symbolizing the danger to her purity; he progresses through the Miller's "rebellious" motive and that of the linden tree, gloriously tonal and secure, to the harmonically simplified world of Hanička and Zajiček for the act's first scene. Soon the two are visited by the forest nymphs, set as an offstage women's choir (much in the spirit of the Nutcracker's "Dance of the Snowflakes"); the score of Novák's corresponding dance rarely steps out of the world of Tchaikovsky, with the exception of a brief, intriguing passage (211-13), which provides one of the only portions of Lucerna's score that reflects its date of composition. Set for woodwind soloists over a chromatically oscillating chordal accompaniment, whose multiple passing tones obstruct their functionality, in this anomalous passage Novák achieves something akin to the expressive realm of Bluebeard's Castle and The Rite of Spring, distantly recalling the opening woodwind solos of each. Most striking here is the fact that the gestures of the woodwind's melody (later given to the full string section over muted trombones and heavy bass pizzicato, example 17) rarely match up to the shifting, harmonically directionless accompaniment: it is possibly Novák's one fleeting moment of extreme tonal disorientation, enacted in a symphonic context away from the dominating symbolism of class and nation. ${ }^{22}$

These symbols immediately return, however, with Hanička's magical disappearance into the tree, effectively unifying the opera's two major focal points of Czechness. As soon as this happens, however, both are threatened by the approach of the Bailiff, ready to assert his party's power by cutting the tree and abducting Hanička. Just in time, the Miller rushes in with all his moral might and threatens the evil-doers in turn-ostensibly the climactic moment of the drama. The linden tree suddenly begins to glow and its motive, again in A-major, re-

22 Interestingly, this very passage is often cut from performances of Lucerna, as indicated by the manuscript score in possession of the National Theatre Music Archive, Prague. 
sounds through the mêlée, putting an end to controversy and allowing Hanička to return to the Miller, that they may declare their faithfulness to each other (227). The sacred atmosphere of the moment is sealed by an offstage chorus, which sings (describing the preservation of either the tree or Hanička): "The pure spirit of kin [is] an ever-firm shield, the source of strength in the struggle of the ages. In it lives a holy inheritance-the work, the dream, and the ancient fight of the forefathers." Defeated, the Princess enters one last time, in order to grant the Miller his independence through the symbolic act of smashing the lantern, thereby securing the safety of the tree and Hanička; she makes it clear that it is his strength of noble feelings that has won this reward, and she departs amid the last moment of impressionism in the opera. From here onwards, Novák's musical language recedes into a glow of tradition as the Miller apostrophizes first Hanička ("my dear soul, my happiness, and my whole strength") and the linden tree ("standing for ages... blessed for ages to come") in terms that rival any nationalist opera of the late nineteenth century. With the linden tree motive thundering through the entire orchestra and a firm C-major cadence (example 18,238), Lucerna's concluding scene attempts to state unequivocally the aesthetic and moral direction for Czech modernism in the early 1920s: back to Smetana and the values of the Cultural Revival.

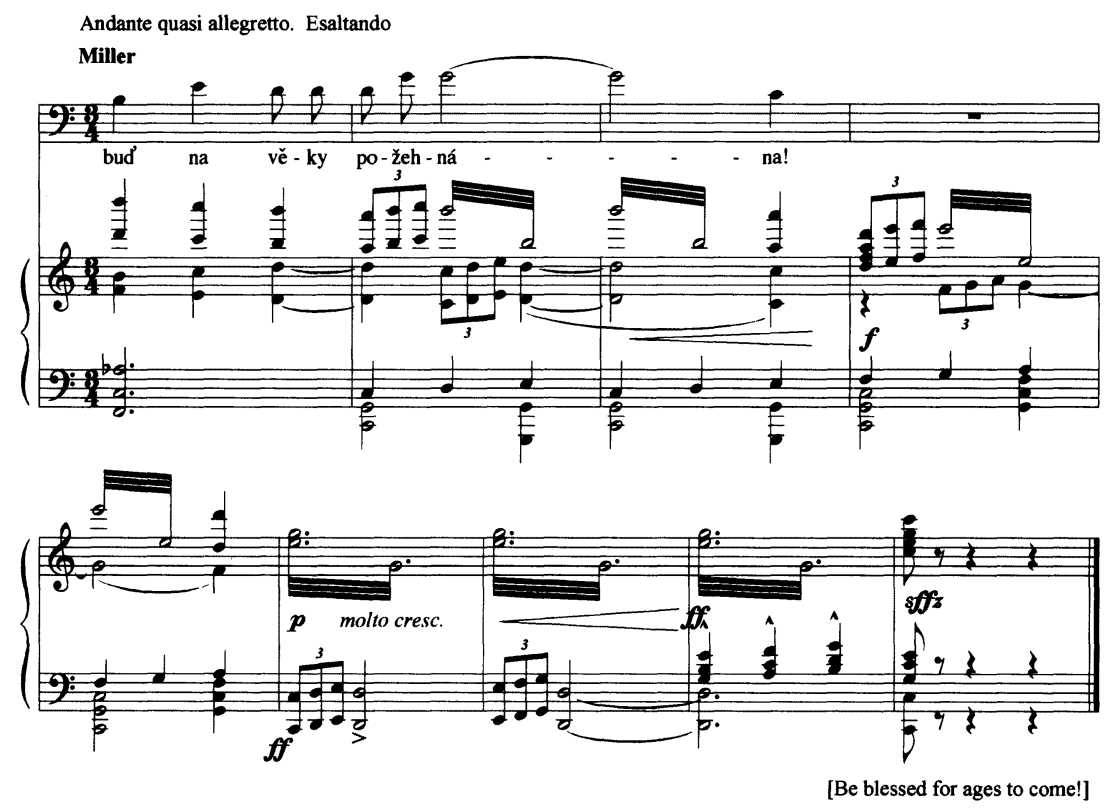

Example 18. Final cadential measures of the opera (Novák 1923, 238, bars 12-20)

These attempts to state such values in unequivocal terms would be fruitless for many reasons. Not even within the musico-dramatic narrative of Lucerna itself is such a nationalist enterprise fully convincing, given the concatenation 
of symbols, associations, and stylistic allegiances throughout the opera and their overly hasty resolution in the final scene. We are told, for example, that the Miller regains Hanička after successfully escaping the seductive wiles of the Princess and her vision of a worldly future. His return, accompanied by conservative music to match, reflects Novák's rapprochement with "timeless" nineteenth-century aesthetics, and/or the turn of his contemporaries away from international modernism in 1923. Read in this way, Lucerna creates the fiction of an unbroken continuity of pure "Czechness" from the Grandmother's legends of the past through the Miller to Hanička, who, having been preserved for the lineage, receives her hallowed gift with wonderment. She merges with the historic linden tree and emerges from it into her new life, thereby renewing the glories of the Czech past for future generations, much as the "Cult of Smetana" had done after 1917. Through Hanička, Novák also resuscitates the Herderian national folkloric project, casting her in musical terms that evoke an Eastern, antimodernist purity, a concept that belies the fundamentally cosmopolitan nature of the opera if taken as a whole.

The Princess and her retinue, as the apparently cosmopolitan characters in the plot, receive a similarly problematic treatment in Lucerna's musico-dramatic narrative, since they are neither demonized nor absolved by the outcome in the final scene-they simply return from whence they came. Similarly unresolved are the supernatural characters, who merely vacate their native environment without further participation in the drama after Act Three. Musically, as we have seen, Novák affords these individuals some of the more passionate and dramatically convincing passages in the opera, giving them a certain modernist edge in localized moments. While the Miller's beatification of the linden tree attempts to negate such musical adventures, the sympathy that Novák creates for both the Princess and Míchal casts doubt on the efficacy of such a victory, particularly in light of the markedly anti-climactic nature of their respective departures. Indeed, although the aristocrats and the water-sprites lie in different dramatic camps and have little interaction with each other, both Jirásek and Novák forge strong parallels between them as "outsiders," excluded from the closed circle of the Miller's family's Czechness. The Princess, a non-Czech human, longs for an affinity with her subjects and their culture; the water-sprites, though non-human, have historically been seen as "Czech" phenomena (especially since Dvořák's Rusalka and Vodník) and Míchal longs for an affinity with Hanička. As they each take their leave to go out into the wide, cosmopolitan world-significantly, against their will, at the hands of the Miller-they reveal poignant emotions that, through soliloquy, address the audience directly, in the absence of dramatic interaction. In so doing, they provide an alternate voice alongside that of the victorious Czechs; moreover, in encouraging sympathy for outsiders in a "nationalist" opera, their uncertain status problematizes Lucerna's national and aesthetic stance overall.

This uncertainty creates problems, reflexively, for the "insiders" as well. For one, the paternal/romantic relationship between the Miller and Hanička goes unaddressed until the end of the opera, and her apparent danger remains murkily undefined throughout. Furthermore, even if we concede the unity of the 
Miller's family as a dramatic entity, we do so at the expense of the larger collective unity of the Czech characters in Lucerna, and therefore of the ideological purpose of the opera. Despite the Revivalist-era tradition of representing the entire Czech people as one disenfranchised but deserving class, Jirásek and Novák both take pains to demonstrate an internal class structure, separating the Miller's family from both the villagers and (especially) the Czech servants of the Princess. Only the Miller's family receives words and music that transcend the mundane details of life, granting its members higher spiritual and intellectual status over Zajíček, Klásková, and the speaking characters, whose "characteristic" music points rather to caricature, especially in the case of the zanily unprofessional and parochial "Czech music" (a self-parody if ever there was one). The Bailiff and Musketeer, meanwhile, are branded as "Judases" who have betrayed the national cause by serving foreign aristocrats and carrying out their destructive plans: they, in the tradition of Smetana's Jan Tausendmark, are the closest to being villains for this opera, and are duly cast out of the collective Czech identity for ideological reasons. ${ }^{23}$ The moral and social hierarchy complete, the Miller and his family appear as first among equals, a mirror of the bourgeois intellectual artists that created this narrative for the national education of their Czech audience, first during the Cultural Revival, and latterly at the start of national independence, shortly after the Grandmother's prophecy had come to pass.

It is in fact the prophecy that forms the key to the problems of musico-dramatic narrative in Lucerna, and moreover points to its inability to capture the full support of the Czech audience in 1923. As opposed to its prototype, the final scene from Libuše in which the entire spectrum of Czech history is predicted as an open-ended narrative, Novák's Grandmother does little more than predict an event that is already in the past. As such, neither the positive outcome of the plot-freedom from subjection and the safety of the linden tree and Hanickanor the larger issue of Czech self-determination could embody a sense of dramatic engagement and social relevance for the initial audience; the opera would instead have presented a closed circle with very little dramatic power. Everything in the middle, then, including the Miller's morally righteous, rebellious tendencies, was ultimately doomed to inefficacy, revealing a conclusion that could only be self-satisfying in the absence of any true climax. This crucial problem speaks to what Lébl described as the central axis of tension in Lucerna and in Novák's mature œuvre in general: caught between the dramatic and the idyllic, neither of which can be said to encompass the music fully (Lébl 1964, 206-08). Without question, Lucerna's idyllic components provide not only a marked degree of entertainment value on the surface of the score-bearing witness to the composer's powers of characterization at their height-but also the moments of transcendence in Act Three, arguably the most well-formed pas-

23 Jan Tausendmark is the German-Bohemian resident of Prague who betrays his fellow citizens to the occupying forces in The Brandenburgers in Bohemia, ultimately to be cast out by the victorious Czechs. Novák's Miller repudiates the Bailiff on similar terms, differentiating him from the Courtier: "You [the Courtier] are of foreign blood and do not have our sensibility, and this one here, the Bailiff, is a dissenter. Judas!" (Novák 1923, 113). 
sages in the opera. Nevertheless, Novák's brief experimentation with the various modernist streams of his generation also appear here as idyllic episodes that, significantly, do not develop into a far-reaching expressive transformation-indeed, the opera's dramatic structure prevents any such open-endedness from occurring.

And yet, these modernist episodes are present and inform the musico-dramatic character of Novák's work. Between all the instances of folk-like melody and harmony, the musical debt to Smetana and Dvořák, the rural setting, and the prevailing use of nationalist symbolism, it is easy to lose sight of the fact that Lucerna is inarguably the work of bourgeois intellectuals from Prague, the Czechs' most cosmopolitan city. Thus, despite appearances to the contrary, its score is far more worldly than its creator, by 1923 , might have cared to admit. Furthermore, its indirect exploration of modernist expression may have been the only way of coming to terms with musical cosmopolitanism in Prague, particularly for a generation that had failed to do so in the early postwar days and had since become convinced of its morally superior parochialism. Novák's changing position within this artistic community may also explain the expressive duality of Lucerna. As a self-proclaimed rebel-artist of the fin-desiècle modernist period, he may have initially shared an outward affinity with his "hero," the Miller. However, in the act of proclaiming the rebirth of nineteenth-century traditions he effectively gave up this musical "rebellion," just as, socially, he made a swift transition from agitating for collective democratic rights before 1918 to happily entering the new oligarchy of cultural politics after independence. Just as the Miller's rebelliousness was ultimately passive and ineffectual, so too was Novák's, his hesitant moderation soon replaced by increasingly powerful and fractious voices demanding ever more extreme resolutions to the question of Czech modernism. Amid the clamour, Lucerna, for all its internal beauty, quickly became the anthem for Novák's passage to premature obsolescence.

The opera's somewhat unenthusiastic reception supports this picture of shifting paradigms and radically changing ideologies in the early days of interwar Prague. ${ }^{24}$ Novák's numerous detractors, including his nemesis Zdeněk Nejedlý, had little good to say about Lucerna, either as a contribution to modern Czech

24 The première, which took place on May 13,1923, at the Prague National Theatre under the direction of Ostrčil, presented its own problems that critics assessed somewhat separately from the style and content of the opera. Initially scheduled for the beginning of the month, announcements for the première came out prematurely, before the opera department was ready to mount such a complex new piece; the event was postponed several times but finally fixed for May 10. Two days before this, Václav Novák, the powerful baritone for whom the role of the Miller had been written, allegedly struck one of the company actors and was suspended from the theatre indefinitely. With only five days' notice to learn the part, Václav Chodounský, a baritone with a substantially weaker voice, performed the role at the première, an exertion that necessitated a two-week recovery. The composer personally blamed Ostrčil for the outcome, citing a lack of respect due his work, despite the fact that the conductor had been virtually powerless between a wayward cast and the scheduling whims of his administration, neither of which allowed his usually meticulous level of preparation. Novák never forgave him. See discussion in Pala 1964, 180-85. 
opera or as a representative of a Smetana-inherited tradition. Nejedlý, as self-appointed spokesperson for this tradition, found that Novák's contemporary trend towards small forms (enacted here in the episodic nature of the scenes) and fairy-tale themes amounted to an overall simplification of expression. This new simplicity might have been welcome, had it not been for the accompanying abdication from progressive ideals Nejedlý perceived in Lucerna's score, in which the composer denied his previous predilection for monumental structures. The lack of internal unity made all aspects of the content ring false: the naïveté forced, the old-fashioned atmosphere joyless, Novák had vainly attempted to make his work appeal to the everyman: "And this would certainly be the saddest fate that could befall Vítězslav Novák: that he, who for us was once the very symbol of the fight for great art against all mediocrity, has now himself become, perhaps unwillingly, an ally of this mediocrity against great art" (Nejedlý 1923, 44). ${ }^{25}$ Nejedly's follower, the critic Hubert Doležil, assessed Lucerna on more specific terms, all the harsher for his attention to detail: for him, Novák's opera embodied all the negative aspects of the transitional era in which they lived, with its "insufficiency of decisive ideas and style-creating principles,... when the art of the past sounds exhausted and used up, but there is neither strength nor clear destination for a new one" (Československá republika, May $15,1923)$. It was one thing to follow the "incomparable model of Smetana," but quite another to "speak his language in a soulless imitation," for "great traditions cannot be incarnated in whatever form, and do not pass into meat and bone." All of Novák's attempts at characterization were therefore misunderstandings of his model, failing to develop the individuals of the drama in any real way: instead of the humour of Smetana and Dvořák's folk characters, Doležil found Míchal's superficial comedy unbearable and the melodrama of the village musicians incomprehensible. Perhaps more damaging, however, was his assessment of the final scene, which, although he welcomed it as the one unified dramatic span in the opera, unfortunately came too late to be seen as anything but embarrassingly self-indulgent. In short, the moment of national transcendence was for nought. ${ }^{26}$

While Lucerna certainly did have its supporters, mostly in the form of ultraconservative critics with their sights set on claiming Novák for their own, most telling is the overwhelming silence with which this opera met, both in 1923 and throughout the following quarter-century of the composer's life. In critical assessments of Novák's extensive œuvre and considerable achievements as a teacher and organizer of cultural life, discussions of Lucerna are usually relegated to a single line, often dismissing it as a product of the misguided lacuna be-

25 Nejedlýs anti-Dvořák agenda, since 1912 directed personally at Novák, would certainly have come into play in this judgment: Lucerna's heavy reliance on dramatic themes and characterizations from Dvořák's operas would have served to distance Novák from Nejedlýs construct of a "Smetanian legacy."

26 Perhaps with this criticism in mind, Novák undertook to strengthen the Miller's final nationalist statements for a production in 1940, adding in the offstage men's chorus with a repeat of their text from earlier in the act. While the effect is certainly one of grandeur, the overlapping phrases, more complicated harmonies and competing texts serve to obliterate the direct expression of Miller-perhaps not a result that Novák intended. The revision appears in the National Theatre performing score, but not in the Supraphon recording. 
tween Pan and the vibrant pantomimes of $1929-30 .{ }^{27}$ Novák himself frequently blamed the coolness of his colleagues on a flawed première and the lackadaisical attitude towards his work at Prague's National Theatre; as his frustration with his loss of prestige and his distance from the musical present grew, he frequently fixated on the Lucerna reception as a turning-point in what amounted to the dishonorable treatment of a "national artist" (Novák 1970). His career-both in the disenchanted eyes of his contemporaries and in his own increasingly selfrighteous estimation - would never be the same again.

It is the strange and unlikely fate of Lucerna to illustrate a cluster of disconnects in the historiography of early modernist music. Clearly, members of the Czech musical community were at odds with each other over their reading of the larger importance of modernist influences in the early interwar years, unable to reconcile their past achievements with the needs of the present. Sadly, their selfrighteous isolationism in the name of a "modern tradition" prevented any truly open interaction with compositional trends in the rest of Europe during one of its most fruitful eras, to the point of hindering the promulgation of their own music abroad. This very isolationism subsequently created a disproportionate estimation of the role of Czech modernism within Czech historiography, itself unable to reconcile the relative importance of the movement with the larger narrative of music in early twentieth-century Europe. But it was also this larger narrative that, in the intervening years, excluded such alternative readings of modernism as misguided, irrelevant, or even antimodernist, even when in themselves they expressed a desire to find the path to an elusive "future of art." No less a modernist figure than the microtonal composer (and Novák admirer) Alois Hába addressed the question of the relevance of Lucerna as an expression of the modern era: "Today, indeed, we must, with a lantern, look for Lucerna in other places [than the past]. Freedom and creative initiative are threatened and limited by other means.... Let it shine on us, so that we perceive in time the dangers, in all their outward and hidden forms, threatening the freedom of humanity" (Hába 1930, 3). Perhaps, through the acceptance of alternative modernisms, we can continue to liberate the early twentieth century from the confines of its historiography.

\section{REFERENCE LIST}

Axman, Emil, 1924. "Nechte cizích, mluvte vlastní řečí!" Tempo-Listy Hudební matice 3/5: 165-70.

Doležil, Hubert. "Novákova opera Lucerna." Československá republika, May 15, 1923.

27 After Lucerna, Novák produced another, even less successful opera, Dédův odkaz (The Grandfather's Legacy, 1926), which solidified his connection with ultra-conservative aesthetics, as well as his distance from contemporary tastes. While, to a certain extent, he regained some of his prestige with the two pantomimes Signorina Gioventù and Nikotina, his status as a cultural leader would return only during the strained years of the Nazi Protectorate, when his efforts towards Czech music making were cast in heroic terms. 
Erben, Karel Jaromír, 1982. Kytice balad. Prague: Československý spisovatel. Griffiths, Paul, 1981. Modern Music: The Avant-Garde since 1945. New York: George Braziller, Inc.

Janeček, Karel, 1970. "Vítězslav Novák v proměnách času." Hudební rozhledy 23/2: 555-64.

Hába, Alois, 1930. "Lucerna." Národní divadlo 8/13: 2-3.

Lébl, Vladimír, 1961. Cesty moderní opery. Prague: Státní hudební vydavatelství.

1964. VitězslavNovák:života dílo.Prague:NakladatelstvíČeskoslovenské akademie věd.

Locke, Brian, 2006. Opera and Ideology in Prague: Polemics and Practice at the National Theater, 1900-1938. Rochester: University of Rochester Press.

Morgan, Robert P., 1991. Twentieth-Century Music: A history of musical style in modern Europe and America. New York: W.W. Norton.

Nejedlý, Zdeněk, 1920. "Vítězslav Novák. K padesátým narozeninám." SmetanaHudebni list 10/9-10: 112-14.

1921. Vitězslav Novák. Studie a kritiky. Spisy menší Zdenka Nejedlého svazek II. Prague: Melantrich.

, 1923. "Letošní novinky Národního divadla v Praze." Smetana-Hudební list 13/3-4: 41-46.

Novák, Vítězslav, [n.d.]. Lucerna. 2 vols. Autograph performance score, incorporating revisions prior to the 1940 National Theatre production. Musical Archive, National Theatre, Prague, sign. H 184.

1923. Lucerna. [Musical folktale in four acts after the play of the same name by Alois Jirásek, libretto by Hanuš Jelínek, op. 56. Piano vocal-score by Roman Veselý.] Prague: Hudební matice Umělecké besedy.

, 1970. O sobě a jiných. Prague: Editio Supraphon.

, 2002. Lucerna - The Lantern. Opera in four acts. Soloists, Prague Radio Chorus, Prague Radio Symphony Orchestra, conducted by František Vajnar. Supraphon CD SU 3642-2 612.

Pala, František, 1964. Opera Národního divadla v obdobi Otakara Ostrčila. Vol. 2. Prague: Divadelní ústav.

Sandow, Greg, 2004. "A Fine Analysis." In Arved Ashby, ed., The Pleasure of Modernist Music: Listening, Meaning, Intention, Ideology, 54-67. Rochester: University of Rochester Press.

Šilhan, Antonín. "Vítězslav Novák: Lucerna." Národní listy, May 15, 1923.

Smetana, Robert, ed., 1972. Dějiny české hudební kultury 1890-1945. Vols. 1-2. Prague: Academia.

Šourek, Otakar. "Vítězslav Novák: Lucerna." Venkov, May 15, 1923.

1923. "Novákova Lucerna (Několik poznámek o povaze díla)." ListyHudební matice 2/8-9: 189-99.

Štěpán, Václav, 1920. "Francouzský vliv u nás. - Blanche Selva." Hudební revue 13/4: 150-53.

Taruskin, Richard, 1996. "Introduction" in Repercussions 5/1-2: 5-20. 
Volek, Jaroslav, 1972. "Novák-'osová' osobnost české moderní hudby." In Vitězslav Novák: Studie a vzpomínky k 100. narozeninám, eds. Karel Padrta and Bohumír Štědroň, 21-42. České Budějovice: Jihočeské muzeum.

\begin{abstract}
The opera Lucerna (premièred 1923) by the Czech composer Vítězslav Novák demonstrates the problematic position of Czech music in the historiography of the early twentieth century, since neither "avant-garde" nor "antimodernist" suffice for it as stylistic labels. A leader of Czech modernism during the fin de siècle, Novák's music embodies the aesthetic crisis his generation faced after 1918. Lucerna's score reveals a complex negotiation of multiple stylistic influences, including impressionism, folklore, and Strauss, paralleling the Czech community's hesitant acceptance of international modernism in the early interwar period. The opera's lack-lustre finale echoes the contemporaneous return to Czech traditional values, using Smetana as an anachronistic model for modernist opera.
\end{abstract}

\title{
RÉSUME
}

L'opéra Lucerna (première en 1923) du compositeur tchèque Vítězslav Novák est un exemple représentatif de la position difficile de la musique tchèque dans le cadre de l'historiographie du début du XXe siècle. En effet, les étiquettes « avant-garde " et " antimoderniste " ne conviennent pas pour décrire ses caractéristiques stylistiques. Un chef de file du modernisme tchèque pendant la fin de siècle, Novák a su transcrire musicalement la crise esthétique vécu par sa génération après 1918. La partition de Lucerna révèle une négociation complexe d'influences stylistiques diverses, telles l'impressionisme, le folklore et Strauss, en parallèle avec le modernisme international hésitant de la communauté tchèque au début de lentre-deux-guerres. La finale sans éclat de l'opéra se fait lécho du retour aux valeurs traditionnelles tchèques, en utilisant Smetana comme modèle anachroniste de lopéra moderne. 